\title{
PENSAR AS RELAÇÕES ENTRE EDUCAÇÃO E TRABALHO: A EXPERIÊNCIA DE LUCIE TANGUY ${ }^{1}$
}

\author{
Stéphane Lembré, Gilles Moreau e Lucie Tanguy ${ }^{2}$
}

Lucie Tanguy é diretora de pesquisa honorária no $\mathrm{CNRS}^{3}$. Suas pesquisas sobre o ensino profissional são imprescindíveis nesse e entre outros campos, pois ela soube articular a sociologia do trabalho e a sociologia da educação. Por essa razão, esse espaço lhe foi conferido nesse número da Revista Images du travail/travail des images, à medida que suas obras a respeito do ensino profissional na França (PUF, 1991) até Enseigner l'esprit d'entreprise à l'école (La Dispute, 2016), assim como numerosos artigos, fizeram história e abriram caminhos abandonados e/ou pouco explorados pela análise sociológica. Mas Lucie Tanguy não se restringiu a uma só especialidade: ela soube também explorar os territórios contíguos, como atestado no livro Les instituts du travail: la formation syndicale à l'université de 1955 à nos jours (PUR, 2006) ou ainda La sociologie du travail en France. Enquête sur le travail des sociologues (1950-1990) (La Découverte, 2011). Convidá-la a retornar a seu trabalho por ocasião dessa entrevista foi, portanto, uma ocasião de compreender como o espírito científico e crítico que nela habita e a impulsiona foram reunidos em suas abordagens de pesquisa.

Esta entrevista foi realizada entre dezembro de 2019 e maio de 2020 por trocas de mensagens eletrônicas, com base em um conjunto de questões inicialmente proposto. E, em seguida, foi enriquecida pelas trocas e reações às versões precedentes.

Questão: Vemos, em seu último livro, Enseigner l'esprit d'entreprise à l'école (2016), uma dedicatória que você fez a seus pais: à sua mãe, empregada doméstica, e ao seu pai que te viu, após a obtenção de seu BEPC ${ }^{4}$ tornar-se "president[e]", ambos sugerindo uma origem social popular. Poderia nos falar mais sobre sua história social e escolar?

LT: Essa questão é embaraçosa e há muito tempo eu hesito em respondê-la. Ela se tornou uma espécie de ritual que deveria ser questionado. Deduzimos, com efeito, muito rapidamente, por meio da biografia dos autores, sua maneira de pesquisar. Hoje essa relutância foi amenizada com a morte dos meus pais, que produziu um tipo de metamorfose interior. Eu me conscientizei plenamente de que o mérito atribuído à pesquisadora que sou, era, antes de tudo, o deles. Eles pagaram um preço alto para estudar as duas filhas, de forma a proporcionar o acesso às profissões intelectuais. Meu pai conheceu a solidão de um operário agrícola emigrante em Beauce ${ }^{5}$, como muitos homens oriundos do campesinato bretão, após a Segunda Guerra Mundial. Minha mãe, ela

\footnotetext{
1 Tradução de Selma Venco, docente da Faculdade de Educação da Unicamp, pesquisadora associada ao Centre de Recherches Sociologiques et Politiques de Paris (CRESPPA).

${ }^{2}$ Diretora de Pesquisa do CNRS - Centre National de Recherches Scientifiques, França; professora emérita de Sociologia da Educação na Universidade de Paris V e de Sociologia do Trabalho na Universidade de Paris VII.

${ }^{3}$ Conselho Nacional da Pesquisa Científica (N.T.).

${ }^{4}$ BEPC - Brevet d'études du Premier Cycle, que atesta a aquisição de conhecimentos (N.T.).

${ }^{5}$ Região no norte da França (N.T.).
} 
também camponesa, precisou retornar à região de origem para educar suas filhas e vivenciar relações violentas com duas adolescentes revoltadas.

Os seis anos de escola primária em um convento, regido pela submissão, tornaram-me rebelde. Dos anos vividos no colégio em uma instituição católica, restou-me a humilhação infligida pelas colegas de classe, filhas de comerciantes, mais bem vestidas, falando melhor do que eu, vinda do interior. No ensino médio público na cidadezinha onde meus pais puderam comprar uma casa, um professor de física e química, em cuja casa minha mãe fazia faxinas, me (e a) convenceu que eu deveria cursar o ensino superior, mas impossível sem recursos. Após o $b a c^{6}$, tornei-me "pioneira" e queria estudar física, mas a universidade era muito distante para que eu pudesse seguir o curso regularmente. Em seguida, candidatei-me a uma vaga de professora dos anos iniciais e fui nomeada em Stains na região parisiense, onde fiquei apenas um ano, pois me sentia pouco à vontade nessa profissão. Então, me inscrevi em literatura na Sorbonne. Das ciências naturais à literatura e às ciências sociais, o caminho foi longo e tortuoso para ser contado. Longe de ser linear, ele foi feito de circunstâncias e de encontros igualmente aleatórios.

Eu iria me silenciar sobre os episódios de trabalho manual realizados durante as férias escolares. Alguns deles necessários para pagar o material escolar, mas, de fato, eles me ofereceram experiências construtivas. $\mathrm{Eu}$ experimentei, trabalhando em pequenas fazendas como pastora no início e mais duramente na colheita da vagem ou de batatas no campo e, em seguida, em uma fábrica de conservas de sardinhas, a resistência física e psíquica que exige o trabalho manual. Parece-me ter incorporado - e depois convertido tais qualidades no trabalho intelectual, como a concentração, a imobilidade do corpo e a resistência, aprendizados difíceis para crianças não habituadas (como destacado por Gramsci). Para minha grande surpresa, um professor de ofício, ex-operário, que entrevistei há trinta anos atrás, me disse: "eu não gostaria de fazer seu trabalho, ficar imóvel em uma cadeira para escrever".

Ao final desse percurso, creio poder dizer que ter vivenciado a injustiça social e a humilhação me influenciaram fortemente nos meus engajamentos intelectuais e políticos. Diferentemente do que disse Pierre Bourdieu sobre a "vergonha de si mesmo", sentida por aqueles que romperam as barreiras entre as classes populares e as classes superiores, eu jamais tive esse sentimento. Por outro lado, a falta de autoconfiança sempre me torturou e me obrigou a superar a mediocridade que me assombrava, trabalhando além do previsto, conservando sempre em mente todos aqueles e aquelas que haviam ficado para trás.

Questão: Você ingressou no ensino superior em um momento em que a sociologia não era muito estruturada no ambiente universitário e acadêmico. O que te conduziu a essa opção, quais desvios, quais encontros, quais leituras, qual formação?

\footnotetext{
${ }^{6}$ Bac, expressão reduzida de baccalauréat, exame equivalente ao ENEM no Brasil. (N.T.)
} 
LT: Eu encontrei Pierre Bourdieu na Argélia em 1961, onde eu estava com meu companheiro. Eu continuei minha graduação em letras modernas na Universidade da Argélia e descobri concretamente a guerra da libertação nacional, na qual eu já estava engajada como todos os demais progressistas. Bourdieu buscava, por intermédio de Abdelmalek Sayad, mulheres para pesquisar nas cidades da periferia. Algumas já o acompanhavam desde a "metrópole". Eu estava no local e imediatamente fiquei encantada com a proposta. Sayad tinha constituído várias equipes mistas, um homem argelino apoiador da $\mathrm{FLN}^{7}$ e uma mulher francesa simpatizante. Eu integrei uma equipe com um estudante de medicina tão ignorante em sociologia quanto eu em medicina. Nós partimos para a pesquisa de campo, sem protocolo, sem questionário, tendo apenas uma orientação: entrevistar sobre todos os aspectos da vida das mulheres (eu) e ele a dos homens.

Eu diria que essa vivência na Argélia durante a guerra de descolonização me levou a situações de perigo de vida, pois estava condenada pelos estudantes pertencentes à $1^{\prime} \mathrm{OAS}^{8}$ e ser arrastada nua pela rua Michelet (equivalente ao Boulevard Saint Michel ${ }^{9}$ ) por ser "aliada" à FLN. Na verdade, eu havia chegado despreocupada, com uma capa preta (o uniforme do $\mathrm{CRS}^{10}$ ) e uma echarpe de seda verde (a cor da bandeira argelina) e eu tinha por hábito me instalar em um restaurante universitário ao lado de um que era frequentado pelos estudantes árabes, sem prestar atenção. Minha participação na enquete de Bourdieu consolidou minha reputação de traidora. Assim que chegávamos às cidades, éramos recebidos a pedradas pelas crianças que insultavam meu camarada em árabe: "como pôde se casar com uma Roumiyal1...". Mas como eu fui aceita pelos adultos, e passei horas entrevistando as mulheres prontas a contar sua vida, e mesmo aspectos, os mais íntimos, aparentemente felizes de falar com uma francesa em uma língua de que tinham pouco domínio. Eu idealizei, talvez, esse episódio, mas nas minhas lembranças ele está na origem do meu interesse por conhecer o mundo social. Bourdieu me cobriu de elogios, dizendo que eu era uma pesquisadora excepcional e me convidou a encontrá-lo, quando voltasse a Paris. Não sabemos o que ele fez com essas entrevistas. Cada um fez seus relatórios, sem nunca ter debatido pontos de vista sobre eles, nem, a fortiori, uma análise. Dito de outra forma, eu não aprendi as bases da profissão, eu apenas experimentei os desafios de um trabalho de campo hostil e aprendi a construir a relação pesquisador/pesquisado.

Na volta a Paris eu me inscrevi em sociologia na Sorbonne e solicitei a Bourdieu para me integrar, como pesquisadora, na equipe que estudava a arte médiai. Eu me senti isolada, privada das discussões e obrigada a mendigar por uma pequena remuneração. Ingênua,

\footnotetext{
${ }^{7}$ Frente Libertadora Nacional (N.T.).

${ }^{8}$ Organização Armada Secreta (N.T.).

${ }^{9}$ Boulevard Saint Michel é uma ampla avenida na cidade de Paris, equivalente à avenida Paulista, em São Paulo, por exemplo. (N.T.).

${ }^{10}$ Polícia Nacional (N.T.).

${ }^{11}$ Segundo Naïma Yahi (2013), designa a mulher europeia, figura oposta à mãe argelina, adorada e dedicada à família. (N.T.)
} 
eu aprendi a divisão do trabalho intelectual e isso me entristeceu. Eu me afastei do meu ídolo que agia de forma oposta aos seus escritos e me limitei a lê-lo nos anos 1980-90, para, em seguida, seguir seus cursos no Collège de France.

Enquanto era inspetora de escola, eu preparei minha graduação em sociologia (tendo como professores Gurvitch, Aron, Passeron) que me conferia, à época, um certificado em economia política, em psicologia social e antropologia. Em seguida, eu participei dos seminários da EPRASS ${ }^{12 \mathrm{ii}}$ onde os estudantes se iniciavam à sociologia empírica ${ }^{\mathrm{iii}}$, assim como em cursos de estatística no $\mathrm{CNAM}^{13}$. Apaixonada pelo conhecimento do mundo social, eu frequentei os seminários de Touraine que me observava, porque eu ousava pedir a palavra, mas nunca me propôs qualquer ajuda para ingressar no ensino superior ou em uma instituição de pesquisa. Foi Viviane Isambert-Jamati, quem criou, então, uma equipe de sociologia da educação no CES (Centro de Estudos Sociológicos) e me propôs uma vaga para participar de trabalhos financiados pela Delegação Geral de Pesquisa no CORDES (instituição com uma política de contratos em ciências sociais, 1966-1975) sobre as desigualdades geográficas de escolarização. Ela me incentivou a me inscrever no concurso do CNRS em 1967 sobre esse tema e fui admitida. Ela me concedeu toda a independência para realizar a pesquisa a meu modo e orientou minhas leituras com base em meus interesses.

Questão: Em 1972, você publicou na Revue française de sociologie, um artigo intitulado "O Estado e a escola. A escola privada na França". Retrospectivamente nós não te imaginamos trabalhando sobre esse tema. Tanto que encontramos, anos mais tarde, em 1977, uma publicação sobre os siderúrgicos de Lorraine, no Maspero (Le capital: Les travailleurs et l'école, l'exemple de la sidérurgie lorraine). Quais caminhos (intelectuais, institucionais, práticos etc.) te fizeram passar da escola privada aos operários? É, ao final das contas, uma continuidade que não vimos espontaneamente?

LT: Não são apenas os objetos de estudo que caracterizam o trabalho de um(a) sociólogo(a), mas a concepção que ele(a) tem de si mesmo o define. Eu sempre quis vincular a pesquisa às transformações sociais. E, assim, eu só fiz seguir o conselho de Durkheim que dizia: "querer estudar a realidade não significa dizer que devemos desistir de melhorá-la". Cada um dos meus temas de estudo está mais ou menos ligado a esse tipo de preocupação. Este é o caso do artigo intitulado "O Estado e a Escola". A escola privada na França, cujas origens foi o debate suscitado pela lei Debré ${ }^{14}$ de $1959^{\text {iv }}$. Essa lei instituiu novas relações entre Estado e os estabelecimentos privados, por meio de contratos que autorizavam o nascimento - ao lado do serviço público, laico e obrigatório -, de um tipo de serviço privado de ensino.

\footnotetext{
12 EPRASS - Enseignement préparatoire à la recherche approfondie en sciences sociales - Ensino preparatório à pesquisa aprofundada em ciências sociais. (N.T.)

${ }^{13}$ Cnam - Conservatoire Nationale des arts e métiers (Conservatório Nacional de artes e ofícios) (N.T.)

${ }^{14}$ Lei Debré, de 1959, permitiu que as escolas privadas firmassem contratos com o Estado e conservaram seu caráter confessional. (N.T.).
} 
Certamente, eu, que frequentei uma escola católica, estava mais consciente em relação a outros sobre o que ainda se denominava "a discussão escolar", e vi o início de um processo de erosão do estatuto da escola republicana, um movimento que permanece até hoje, sob outras formas e impulsionado por outros atores. ${ }^{\mathrm{v}}$

O fato de se ater à cronologia das publicações pode induzir a mal-entendidos, fazendo crer que há uma continuidade, onde há, frequentemente, descontinuade ou simultaneidade.

Publicar um artigo demanda menos tempo do que escrever e editar um livro. "O capital, os trabalhadores e a escola, o exemplo da Lorraine siderúrgica", que publiquei em $1976^{\mathrm{vi}}$, tem sua origem no fracasso de um estudo anterior que Viviane Isambert nos solicitou (à Monique Segré e a mim) e que tratava das variações geográficas da escolarização na França, cujos percentuais compreendiam (para as crianças de 11 a 14 anos nas classes do $6^{\text {ème }}$ aos do 3ème) de $30 \%$ na Mayenne ${ }^{15}$ a $78 \%$ no Baixo Pirineus. Pensado em termos de mensuração, utilizando os instrumentos estatísticos inadequados ao fenômeno estudado, hoje ilegível, este estudo, todavia, foi publicado em um número especial da Revue Française de Sociologie, em 1968, cujo objetivo era relatar os trabalhos conduzidos em dois grupos de pesquisa: uma equipe do CES, dirigido por Viviane Isambert-Jamati e, outro, coordenado pelo Centro de Sociologia europeia, na pessoa de Pierre Bourdieu. ${ }^{\text {vi }}$

A esterilidade dessa análise orientou-me a uma abordagem totalmente diferente, um tipo de monografia. Moselle ${ }^{16}$ me pareceu um caso particularmente interessante porque, em 1968, 35,4\% dos filhos dos operários, com idade entre dezesseis e dezoito anos, eram escolarizados em escala nacional, ainda que na mesma data essa taxa atingisse $60 \% \mathrm{em}$ Ariège e somente $28.2 \%$ em Moselle.

Além disso, toda a construção social portava a marca do grande capital com os trusts da siderurgia. Mais da metade da população ativa era constituída de operários da grande indústria. Essa concentração da classe operária engendrava uma forte polarização das classes sociais. Naqueles anos, as crianças nascidas e formadas em Moselle eram preparadas para renovar a força de trabalho já ocupada pelos pais nas usinas e minas. Assim, identificamos, a olhos vistos, os principais protagonistas que dividiam a formação dos trabalhadores: o Estado, a Igreja e o patronato.

Depois dessa pesquisa de campo, percebi o que iria acontecer em razão da minha experiência: os CETs (Colégios de ensino técnico), desprezados por uns, mas pesquisados por outros, são um desafio político. viii

\footnotetext{
${ }^{15}$ Região no Loire (N.T.)

16 Região no Loire (N.T.)
} 
Acessíveis unicamente por concurso até $1967^{\mathrm{ix}}$, os CETs emitiam diplomas profissionais reconhecidos, até as últimas duas décadas, nas grades de classificação das convenções coletivas, reconhecimento conferido pelo código do trabalho ${ }^{17}$; interpretação aportada pelas organizações operárias, mas ignorada ou negada por grupos políticos que pretendiam ser os porta-vozes da juventude estudantil nas manifestações da época "os CETs já são uma fábrica".

Eu concluo esse estudo apoiada em uma ideia cultivada pelo movimento operário desde a Comuna de Paris, da Internacional de ensino, das reflexões de Kroupskaia, de Maïakovski, de Gramsci: um ensino politécnico que une o trabalho intelectual e o trabalho manual para formar trabalhadores cultos, aptos a organizar e a dirigir a produção, a pensar e agir sobre todos os aspectos da vida social. Uma utopia a qual a mente necessita conceber, ainda que em um horizonte distante.

Após essa pesquisa, eu me senti liberta da vontade de fazer ciência sobre o modelo das ciências naturais, postura que ainda orientava meus trabalhos precedentes, conforme um artigo acima citado. Ao fazer isso, abracei a teoria marxista ou uma vulgata dela que corrigirei em seguida.

Questão: Você fez parte de uma geração marcada pela Guerra da Argélia, maio de 68 e dos anos 1970. Como você viveu esse período onde os debates de ideias e as ações políticas estavam em plena efervescência? Quais engajamentos, quais distâncias? Quais visões? Qual era o lugar da sociologia, em sua compreensão, sobre o que acontecia naquele momento? Quais efeitos sobre a sua própria concepção de sociologia?

A experiência da guerra na Argélia, a da luta pela libertação ("Vietnam-Laos-Cambodge même combat"18), as manifestações antifascistas e, claro, sobre a explosão de maio 1968 com todos os seus extremos. Eu participei de diversas ações como a distribuição de batatas aos operários da Citroën, nas assembleias gerais do $\mathrm{CES}^{19}$ durante as quais nós nos defrontamos sobre a concepção das reformas ou revoluções a serem feitas no futuro. Eu nunca acreditei que as condições estavam reunidas para isso, eu detestava o abuso de alguns em relação às pessoas mais velhas, membros do partido comunista, que haviam arriscado sua vida se engajando na resistência. Eu me manifestei, como todo mundo, gritando: "a pesquisa a serviço dos trabalhadores" e sem aderir aos slogans grandiloquentes, alguns até poéticos, reivindicando uma liberdade sem limites, como "é proibido proibir". Eu conhecia o adversário por experiência e sabia que não se podia subestimar sua força. Eu admirava a inventividade dos estudantes que deflagraram essa contestação radical de um regime político, mas eu desconfiava, pois eles estavam muito fechados em suas próprias ideias.

\footnotetext{
${ }^{17}$ Equivalente à CLT brasileira (N.T.)

18 Publicação n 14 dos “Cahiers Rouge" Vietnam, Laos, Cambodge Même Combat! Ligue Communiste. 1970 Reliure inconnue $-1^{\text {er }}$ janvier 1970 (N.T.)

${ }^{19}$ Centro de Estudos Sociológicos (CNRS) (N.T.)
} 
Naqueles anos, uma corrente tentava implantar um estilo de pesquisas reduzindo os fenômenos sociais a variáveis, à medida que a relação entre elas visava construir modelos explicativos. Raymond Boudon encabeçava essa corrente de pensamento, cuja tese, em 1964, tinha como título “A análise matemática dos fatos sociais”, a quem Raymond Aron disse durante a minha defesa: "Você é a encarnação viva da aceleração do progresso científico". Sua publicação foi recebida no mesmo tom das revistas acadêmicas. A crítica feita em Annales (em 1969) anunciava "Aqui está uma obra em que podemos apostar será feita uma referência em futuro próximo como "o Boudon"xi A metodologia está na ordem do dia e Raymond Boudon com Paul Lazarsfeld (sociólogo americano por ele convidado) publicaram manuais reunindo um número importante de pesquisas empíricas: "Le vocabulaire des sciences sociales, concepts et índices" (1965), "L'analyse empirique de la causalité" (1966) ${ }^{\mathrm{xi}}$. Eu conservei a ideia que um rigor no método de observação e de análise é uma exigência de todo conhecimento objetivo e, se possível, científico, bem como de ações. Em 1968 eu me afastei dessa corrente de pensamento - como muitos outros da minha geração - e, com alguns amigos engajados nas lutas dos trabalhadores, nós constituímos um grupo de leitura d'O Capital onde cada um deveria coordenar o debate sobre alguns capítulos. Essa leitura aplicada e exigente, influenciaria notadamente a orientação de nossos objetos de pesquisa e de nossos esquemas de análise. Inconscientemente, nós nos voltamos à teoria marxista da qual nossos predecessores se desviaram. (ver artigo de Jean-Daniel Reynaud no primeiro número da Revue Française de Sociologie $e^{x i i i}$ após tê-la abraçado alguns anos antes).

A questão da separação da escola e do trabalho se exacerbou nos anos 1970 correlativamente à extensão da escolarização. É nesse contexto que emerge o princípio de alternância, como resposta às contradições inerentes ao ensino profissional integrado à escola. A referência à experiência alemã, já comemorada por Jules Ferry e os ministros da Instrução Pública, que o seguiram, retornou como modelo a ser experimentado ao qual se opuseram os partidários de uma forma de democratização escolar. De fato, no final dos anos 1970, 40\% dos jovens alemães de treze anos eram orientados para o aprendizado. Realizado essencialmente nos locais de trabalho, no âmbito de uma cogestão entre o patronato e os sindicatos dos trabalhadores, esse modo de formação é acompanhado por um reconhecimento do operário qualificado, passagem obrigatória para ser promovido a contramestre ou mesmo a um engenheiro de produção. Mas, seria essa formação, desprovida de acesso à cultura geral, favorecedora de uma socialização capaz de valorizar o trabalho como fonte de conhecimento e de auto- realização? Essa foi a pergunta que me perseguiu nessa pesquisa sobre a formação profissional na República Federativa da Alemanha. (RFA).

A experiência na República Democrática Alemã (RDA) pareceu-me igualmente instrutiva. Com base em uma história comum com a RFA, ela se construiu, logo após a Segunda Guerra Mundial, sobre bases econômicas e políticas que romperam com seu passado: nacionalização dos meios de produção e distribuição, planejamento econômico e liderança do Estado que se autoproclama marxista-leninista: o SED (Partido Socialista Unificado da Alemanha). Na RDA, a vinculação entre escola e produção constituiu-se no 
princípio básico do ensino politécnico característico da escola obrigatória de dez anos e comum a todos. O ensino politécnico - que representava o núcleo de um pensamento operário em matéria de educação -, foi progressivamente instaurado naquele país ao longo dos anos 1950-1980 xiv . Boa ocasião, consequentemente, para estudar a escola, posto que ela se abria desde muito cedo ao mundo da produção e do trabalho; para observar como e em quais condições o trabalho portava um valor educativo e poderia se tornar objeto de ensino (ao lado e vinculado à escola); para analisar quais tipos de relações as duas instâncias estabelecem entre si: cooperação, dominação ou compromisso? Essa pesquisa sobre a formação profissional nas duas Alemanhas esbarrou em um conjunto de obstáculos: um conhecimento muito superficial das questões de ambas, a dificuldade de se extrair da representação comum; e, na RDA, o controle do partido dirigente sobre a pesquisa. O livro - L'école et l'entreprise, l'expérience des deux Allemagne (com Annick Kieffer, $1982^{\mathrm{xv}}$ ) - retrata essa experiência, mas ele quase não despertou interesse, sobretudo porque, no mesmo ano, foi lançado outro mais ambicioso assinado por Maurice, Sellier, Sylvestre: Politique de l'éducation et organisation industrielle en France et en Allemagne, essai d'analyse sociétale. Essa obra tornou-se uma referência, especialmente para os sociólogos do trabalho. A interpretação defendida pelos autores foi desmentida na última década pelo crescimento da pobreza, pela perda da centralidade do "sistema dual". Um número especial da Revista Formation Emploi dedicada à aprendizagem na Alemanha, de maneira bem documentada, faz notar todas as transformações que afetam o sistema dual após cerca de duas décadas. Longe de validar a idealização feita pelas políticas públicas e pela mídia francesa, o quadro elaborado por diferentes autores fez emergir as contradições que minam esse sistema e autorizam Mona Granato e Gilles Moreau a qualificá-lo como o "colosso de pés de barro"xvi .

Um dia, eu recebi uma carta de Lucien Sève dizendo que eles (subentendido os membros do partido comunista) não souberam se apropriar das ideias da nossa pesquisa sobre a RDA. Nosso livro caiu, sem dúvida, no esquecimento e, entre outras coisas, por falta de interesse por esse tipo de questionamento e também pela ausência de conclusões inspiradoras. Lembramos simplesmente que a ligação escola-produção era, de longa data, reivindicada por uma maioria do movimento operário e, particularmente, pela sua corrente marxista que via nela um instrumento viabilizador para se iniciar a divisão social do trabalho, um meio de promover o desenvolvimento do "homem" em suas múltiplas capacidades. Segundo essa tese, aprender na produção é aprender a fazer, mas também a pensar e a organizar a produção e decidir seu sentido. No entanto, embora se afirme como doutrina marxista, a educação profissional na Alemanha na RDA visou formar um trabalhador qualificado e eficiente, mas não um ser social capaz de refletir sobre o sentido e a organização social da produção.

Porém, ao querer defender, a todo custo, uma escola apartada do mundo do trabalho, não desprezamos o trabalho manual e não legitimamos seu caráter dominado negando seu valor e sua necessidade, a hierarquia de salários e o posicionamento social? Eram esses os termos que pensavam à época, muito abstratos e presos a uma teoria marxista excessivamente doutrinária. 
Durante a década de 1980, aprofundei a abordagem implementada nos estudos sobre a Alemanha, refinando-a metodologicamente, inspirando-me na perspectiva avançada tecida por autores britânicos, como Basil Bernstein e Michel Young ${ }^{\text {xvii }}$. Tentei (com Viviane Isambert-Jamati) influenciar o mainstream da sociologia da educação, que estava menos interessado no que acontecia nesta "caixa preta" que é a escola, do que no que dela sai.

Os sociólogos ingleses e estadunidenses se propuseram a analisar o currículo formal e o oculto, ou seja, analisar a forma como o conhecimento é organizado, transmitido e avaliado nas instituições de ensino. Esses sociólogos cumpriram sua agenda considerando o currículo como uma espécie de retransmissão de poder fora deles (domínio de uma classe sobre outras, de um sexo sobre outro, de uma raça etc.). Ao contrário deles, cujo trabalho não era conhecido na França até os anos 1980, eu me dediquei a estudar concretamente o conteúdo do ensino, as características sociais dos professores e suas práticas.

Considerando que a produção e a apropriação do conhecimento são, ambas, um aspecto da luta das classes sociais, eu me propus a questionar a instituição de ensino que tem como missão primordial instruir o povo em sua totalidade e em sua diversidade. Quais categorias de saberes a escola seleciona entre todos os produzidos e em uso na sociedade em um determinado momento? Como ela organiza essas diferentes categorias de conhecimento para definir os programas das várias correntes educacionais? Enfim, quais são os mecanismos que regem a distribuição dos saberes?

Durante uma conferência organizada por Viviane Isambert-Jamati na Sorbonne, Young se surpreendeu com a construção dos indicadores usados para responder às perguntas que fiz: a duração da escolarização, os tempos dedicados às diferentes disciplinas, o valor atribuído a elas nos exames etc. Eu estava tentando, de fato, combinar a teoria e a administração de evidências, por meio de indicadores que pudessem ser usados, com vistas a verificar a veracidade dos fatos observados (Savoirs et rapports sociaux dans l'enseignement secondaire en France, RFS, 1983) ${ }^{\mathrm{xviii}} 20$.

Paralelamente, concentrei este estudo sobre "os conhecimentos ensinados aos futuros trabalhadores (Sociologie du travail, 1983), utilizando o mesmo método, mostrando assim que, naquela época, a escola proporcionava melhor aprendizagem das técnicas, do que sobre as condições de trabalho e esta discordância entre as duas aprendizagens justificava, aos olhos dos dirigentes, a busca de novas modalidades de formação, a partir da alternância escola-empresa. Ao comparar uma série de temas presentes nos exames do $\mathrm{CAP}^{20}$ francês e no baccalauréat ${ }^{21}$, verificamos que o ensino profissional ofereceu conhecimentos sobre as matérias e os processos de produção, mas não os necessários à formação do ser social e do sujeito político ((L'enseignement du français au LEP, miroir

\footnotetext{
${ }^{20}$ Certificado de aptidão profissional (N.T.)

${ }^{21}$ Exame ao final do Ensino médio que confere acesso ao ensino superior, equivalente ao ENEM no Brasil (N.T.)
} 
d'une perte d'identité (com Catherine Agulhon e Françoise Ropé, Études de linguistique appliquée, 1982).

Naquela época, parecia-me ter feito pesquisas obedecendo a dois princípios que regiam meu engajamento intelectual: a divisão dos saberes, oferecida pela educação geral, e a educação profissional constitutiva da divisão de classes sociais e a objetivação dos mecanismos envolvidos nesse processo. Dito de outra forma, continuei apegada a uma perspectiva inspirada no marxismo, mas desconectada da teoria geral e preocupada em recuperar minhas observações e interpretações o mais rigorosamente possível. Não creio que esses artigos tenham sido de grande interesse para os sociólogos da educação por desconhecerem a educação profissional, nem para os sociólogos do trabalho que não tinham a formação inicial dos trabalhadores como campo de estudo. Um dia soube, por acaso, que esse estudo sobre o ensino do francês no LEP ${ }^{22}$ estava programado nos Institutos Universitários de Formação de Professores (IUFM) ${ }^{\text {xix }}$.

O desconhecimento acerca da trajetória profissional dos serviços administrativos do Ministério da Educação Nacional constituiu-se em uma oportunidade para que eu continuasse a investigação sobre os professores da educação profissional. Uma extensa enquete realizada em colaboração com o $\operatorname{SPRESE}^{23}$ (mais tarde denominado DEP Direção de Avaliação e Prospecção) em 1983-84, com base em uma amostra representativa da população de professores de mecânica e eletrônica, especialidades que reuniam, respectivamente, 34 e 16\% dos alunos matriculados nos liceus profissionais industriais, seguida por entrevistas realizada com oitenta e sete professores.

Esse trabalho foi realizado em 1985-86, momento em que se aceleravam as mudanças na organização da formação e da seleção de professores, que marginalizavam aqueles oriundos de carreiras operárias. Tais transformações, a princípio, pareceram-me como tantos outros obstáculos encontrados na coleta de informações padronizadas, mas acabaram se revelando como condições privilegiadas para observar o significado dessas mudanças e os métodos de sua implementação. A consciência muito aguçada que os agentes têm disso - por meio das clivagens e conflitos que elas suscitam -, o seu estado desigual de progressão, ofereceram ao sociólogo situações que, em muitos aspectos, se assemelhavam às vividas hoje, conforme demonstrado pelas reflexões emitidas por um entrevistado entre cinco na seção "opiniões livres”, que figurava ao final do questionário.

"Nessas condições, vamos em direção à morte?" Quem vai nos morder? O privado? Chegaremos à aposentadoria? Pouco provável. Temos cabeças pensantes para evitar o sucesso dessa reforma - já desatualizada ou inaplicável - para colher os frutos? (Professor de mecânica, antigo operário profissional, nascido em 1942, nove anos na Educação Nacional).

\footnotetext{
${ }^{22}$ LEP - Liceu de Ensino Profissional (N.T.)

23 Serviço de previsão, de estatísticas e de avaliação, vinculado ao Ministério da Educação (N.T.)
} 
"Se ainda me restasse alguma esperança de que pudesse despertar do objeto dessa pesquisa, meu desejo seria que houvesse uma verdadeira adaptação dos nossos estabelecimentos à realidade de um mundo em contínua evolução tecnológica".

"Demandam-nos muito, mas não nos dão NADA".

"Chegamos ao paradoxo extremo de formar técnicos da indústria em temas que nós não fomos atualizados" (antigo operário profissional, eletrotécnico, 46 anos, 20 anos na Educação Nacional) ${ }^{\mathrm{xx}}$.

É suficiente, então, associar as regras do trabalho científico às qualidades do observador e ter uma boa escuta do outro para captar a diversidade de uma realidade em movimento. A abordagem sociológica beneficia-se ao se somar à etnologia (observações: do ambiente como um todo, das oficinas, da participação em refeições, das pausas para o café etc.).

A mudança em curso - que antes se dava na seleção dos concluintes do ensino técnico superior -, dá lugar a uma elite de trabalhadores profissionais instituída nas décadas de 1940-60, transformando, inevitavelmente, as práticas educacionais e os conteúdos ministrados.

Os saberes dos métiers dão lugar a saberes técnicos. A análise desenvolvida a partir dessas pesquisas e observações in situ resultou no livro L'enseignement professionnel en France, des ouvriers aux techniciens (1991) ${ }^{\mathrm{xxi}}$, e seguiu um duplo desenho: trabalhar com base na memória, registrando as práticas e os valores desses ex-trabalhadores profissionais que construíram essa formação por mais de trinta anos, e construir um método de análise que esclarecesse a natureza das instituições pelo que elas são ou se tornaram e que se aplicasse - às formas e aos conteúdos dessa atividade social -, à formação profissional.

Assim como a situação dos entrevistados, o estudo sociológico dessa categoria de professores permaneceu um tanto obscuro em comparação com aquele que, talvez, se opusesse, mas de maneira muito tímida. Claude Grignon via na educação profissional uma aprendizagem na disciplina e na submissão; enquanto eu queria mostrar que ela transmitia os saberes que constituem a qualificação dos trabalhadores e reconhecida no mercado de trabalho ${ }^{x i i}$. Foi ao lado desses profissionais que percebi a importância da formação profissional para a classe trabalhadora.

Aos olhos dos pesquisados, o estudo sociológico dessa categoria de professores ficava ainda à sombra, se comparado aos que eles talvez combatessem timidamente.

Ao passar muito tempo em campo observando-os, analisando suas práticas, suas visões das mudanças em curso, sem tentar teorizar rapidamente, eu entrevia que esse ensino era orientado para o perfil técnico, abandonando o do trabalhador qualificado. Todas essas pesquisas, feitas na década de 1980, conferiram-me uma especialização pouco atraente: a educação profissional. Nada surpreendente que, ao final dessa década, fui convidada pelo Secretário de Estado da Educação Técnica e Profissional para realizar uma missão 
que pretendia legitimar o "nível V", a nova denominação dada à educação profissional, em referência à nomenclatura dos níveis de formação elaborada durante o Quarto e Quinto Planos ${ }^{\mathrm{xxiii}}$. Voltarei a essa experiência mais tarde.

Questão: Vários de seus trabalhos portam uma dimensão sócio-histórica marcada, como o livro Les instituts du travail. La formation syndicale à l'université de 1955 à nos jours (2006) ou La sociologie du travail en France. Enquête sur le travail des sociologues (1950-1990) (2011).

Qual é a sua concepção da relação entre história e sociologia? Quais têm sido suas colaborações de pesquisa com historiadores e de que forma você vê as virtudes heurísticas? Como a história permite refletir sobre outros caminhos que poderiam ter sido possíveis?

Eu creio que posso dizer que a quase totalidade dos meus trabalhos, à exceção dos primeiros, se inscrevem em uma perspectiva sócio-histórica. A priori, este campo de pesquisa sobre os professores dos ensinos profissional e técnico não se dedicava a isso: ancorado no presente e constantemente demandado a se projetar para o futuro, com vistas a antecipar as qualificações necessárias demandadas pelos representantes das grandes empresas nos anos futuros; em vez disso, esses estudos sustentaram-se no debate social. Mas, não nos esqueçamos de que são, libertando-se dos conflitos, os mais visíveis, que os pesquisadores em ciências sociais conseguem definir os questionamentos e os esquemas de inteligibilidade de uma realidade formatada por conflitos e compromissos de suas soluções. Os historiadores estiveram à frente, em relação aos sociólogos, nesse campo.

Durante a década de 1980, os ensinamentos profissionais e técnicos foram objeto de recorrentes reformas, em grande parte um prolongamento das impulsionadas nas décadas precedentes, e concernentes tanto aos conteúdos do ensino (redefinidos a partir dos referenciais de emprego), quanto aos diplomas (a criação do baccalauréat profissional, por exemplo), os modos de seleção dos docentes, a instauração de toda sorte de estágios nas empresas etc. Essas intervenções políticas, frequentemente elaboradas em resposta às evoluções sociais e demográficas - e em nome da valorização do ensino - dizem querer estabelecer paridades ao ensino geral, que permanece como modelo de referência. É nesse contexto que os historiadores e sociólogos se encontram após terem trabalhado no bojo de suas respectivas disciplinas e formarem um pequeno círculo de trocas e cooperação. O número especial da Revista Formation Emploi (1989) pode ser considerado como uma ilustração desse encontro de interesses entre historiadores e sociólogos para explorar um campo que Pierre Caspard, diretor do Serviço de História da Educação, do Instituto Nacional de Pesquisa Pedagógica (INRP), estimou ainda ser deserto naquela data.

${ }^{x x i v}$ A resenha que fui convidada a realizar alguns anos mais tarde, não está isenta da subjetividade, uma vez que eu mesma integrei esse meio, ainda que restrito, de pesquisa. ${ }^{\mathrm{xxv}}$ 
Essa maneira de fazer "com a história", que não havia sido premeditada, impôs-se como uma evidência proveniente tanto pelo objeto em si, quanto pelo meu aprendizado em sociologia ao lado de Viviane Isambert-Jamati, que desenvolvia uma perspectiva sóciohistórica no momento em que o estruturalismo triunfava (Crises de la société, crises de l'enseignement (1970) ${ }^{\mathrm{xxvi}}$ Les savoirs scolaires, enjeux sociaux des contenus d'enseignement et de leurs réformes (1990)). Ela o fez discretamente à maneira durkheiminiana na L'évolution pédagogique en France (1938), ao destacar a pluralidade dos tempos sociais. Mais que ensino geral, as formações técnicas e profissionais sempre foram objeto de críticas, pois não se adaptavam aos imperativos técnicos e econômicos do momento. Como muitos dos jovens pesquisadores, eu tinha a tendência a olhar o novo, onde somente as formas de um mesmo fenômeno se alteravam. Eu, às vezes, reclamava, mas ouvia aquela que me ensinou a pensar o social em movimento. Mais tarde, eu trabalhei por vários anos com Guy Brucy (historiador) que me formou para a observação das diferentes temporalidades da evolução das instituições, dos conteúdos de ensino, dos professores. Sociólogo de formação, após ser professor de matemática, Jean-Michel Chapoulie, também sempre defendeu a observação das questões sociológicas ao longo do tempo, a fim de evitar os efeitos perversos do presenteísmo.

Instrumento de socialização na hierarquia social, a escola é também uma questão política para acessar o conhecimento, hoje questionada pela celebração das virtudes da aprendizagem na empresa e da aquisição do espírito empreendedor. Para melhor apreciar a amplitude, o sentido das mudanças em curso, eu recorri aos grandes projetos e experiências marcantes, que foram fontes de proposições. Essa volta ao passado antigo de mais de meio século não é originário de uma nostalgia, nem tampouco de fazer revivêla. Historiadores, como Marc Bloch, lembraram, com insistência, que a ignorância do passado é prejudicial não somente ao conhecimento do presente, mas à ação em si mesma. É essa convicção que me move ao retornar a certos períodos da história ou das experiências de emancipação que ocorreram. Extraí-las do esquecimento é uma das tarefas do sociólogo e do historiador, a fim de vislumbrar possibilidades de acontecimentos. Assim, o famoso plano Langevin-Wallon ${ }^{24}$ anunciado ao fim da Segunda Guerra Mundial, refundava as bases do sistema educativo. Embora continue sem aplicação, esse texto constituiu-se em uma referência, frequentemente evocada para justificar as reformas escolares até os anos 1970. Ele representa, ainda, a expressão de uma escola democrática, extrapolando os limites da escola republicana. ${ }^{\text {xxvii }}$ Para esses reformadores, tratava-se de formar tanto técnicos competentes quanto cidadãos esclarecidos. Eles não visavam à instauração de uma sociedade sem desigualdades, mas a uma sociedade na qual as elites seriam múltiplas. Para eles, o ato educativo é um ato político e a pedagogia não é somente um assunto dos docentes, uma vez que a igualdade de direito à educação é também um direito dos trabalhadores para a emancipação intelectual e cultural. Georges Friedmann, um dos fundadores da sociologia do trabalho na França, é também um representante dessa corrente de pensamento disposto a definir um ensino técnico que competiria com o ensino secundário científico e literário. Ele se

\footnotetext{
${ }^{24} \mathrm{O}$ plano referia-se à reforma do ensino e do sistema educacional francês em 1944. (N.T.)
} 
empenhou no convencimento de seus contemporâneos que "a humanização da técnica é uma das grandes missões e, sem dúvida, essencial para o século XX. Esta é uma primeira urgência à formação dos cidadãos que deve ser pensada, pesquisada e realizada"xxviii Esta ideia de colocar em debate os fundamentos da universalização associado ao ensino geral ainda me parece ser cultivada hoje e talvez mais do que ontem.

Considerando ser necessário voltar à minha disciplina, que tinha pouco interesse nesse assunto que passou a ser meu, eu decidi questionar novamente a história da sociologia na França. A pesquisa que realizei sobre o nascimento da sociologia do trabalho na França e sua implantação até os anos $1990^{x x i x}$ foi um novo projeto que se impôs após a enquete sobre os Institutos do Trabalho ${ }^{\mathrm{xxx}}$. Segundo a maior parte dos autores interessados na história da sociologia do trabalho francesa e os manuais que a divulgaram, esse nasceu no Centro de Estudos Sociológicos (CES-CNRS). O exame dos fatos que permaneciam ignorados e foram descobertos nos arquivos, me pareceu que esta proposta deveria ser corrigida para fazer emergir o lugar ocupado pelo Instituto de Ciências Sociais do Trabalho no surgimento da disciplina. Essa iniciativa criada pelo Ministério do Trabalho, fez com que o Instituto rapidamente solicitasse uma pesquisa aplicada aos problemas do trabalho. Essa política, impulsionada no quadro da "modernização" da França nos anos 1950, foi ao encontro das expectativas dos jovens pesquisadores recém-contratados pelo CNRS. Essa política, impulsionada no quadro da "modernização" da France nos anos 1950, vai ao encontro das expectativas de jovens pesquisadores recrutados fazia pouco no CNRS. A pesquisa mencionada acima relata a concretização desse encontro e a herança que ela deixa: um estilo, uma corrente de pesquisa e uma revista.

Esta pesquisa, realizada essencialmente com base em diversas fontes de arquivos combinados com entrevistas, revelou-se fecunda, a meu ver, particularmente pelos erros cometidos durante seu desenvolvimento. A aprendizagem do métier de sociólogo está no cerne do curso e guia a pesquisa feita por questionários ou por entrevistas, a observação das situações, a exploração das fontes secundárias de caráter estatístico, especialmente, mas não à consulta e à pesquisa em arquivos. É por essa razão que Fernand Braudel preconizou uma disputa com Georges Gurvitch (1958), ao ponderar o tempo nas ciências sociais, deplorando a ignorância dos sociólogos. Aos olhos deste historiador, ao limitarse a observar o atual, a sociologia restringe-se a ser "uma sociologia movida por eventos e sobrecarrega bibliotecas e caixas dos governos e das empresas, sem valor científico porque foi incapaz de registrar e compreender o sentido do movimento de todo o fenômeno social". E ao acrescentar - para colocar fim aos conflitos entre historiadores e sociólogos -, seu desejo de ver os jovens sociólogos ocuparem "em seus anos de aprendizagem, mesmo nos mais simples depósitos de arquivos, uma questão básica da história: que passem, ao menos uma vez, em contato com um métier simples, fora dos manuais esterilizantes, mas que, como tantos outros, só se aprende na prática"xxxi

Eu descobri muito tarde a exatidão desse julgamento, após ter pesquisado nos arquivos, bastante diversos, da Maison des mineurs de Piennes (para estudar a reconversão industrial na região mineradora da Lorraine), aqueles da associação dos primeiros 
diretores de pessoal das grandes empresas (a fim de perceber como a formação profissional contínua foi promovida), outros do Plano (para observar como a noção de formação tomou o lugar da educação e colocada em diálogo com o emprego) ou, ainda, o dos Institutos do Trabalho mencionados anteriormente e do CNRS. O trabalho sobre os arquivos é, a meu ver, uma proteção contra as formalizações precipitadas e as teorias abstratas, ou simplesmente contra "os discursos sobre». Assim, eu avancei a pequenos passos, por tentativa e erro para tornar mais inteligível as diversas questões sociais que eu abordei.

Questão: Você é reconhecida em sociologia, entre outras, pela vontade sistemática de articular a sociologia do trabalho e a sociologia da educação e, portanto, descompartimentalizar um campo acadêmico constituído de sociólogos especializados que são talvez "potentados" ou "campos de caça privados". Como foi para você construir intelectualmente esse imperativo de vincular a sociologia da educação e a sociologia do trabalho? Quais finalidades? Quais virtudes heurísticas você viu nisso? Como sua mensagem foi compreendida?

Como responder a essas questões se não admitir os vínculos nos quais as circunstâncias e o acaso, sem dúvida, abriram caminhos. Depois de ter percorrido o caminho, eu poderia dizer: porque o trabalho foi, antes de tudo, por necessidade no início da minha vida e que a escola surgiu, aos olhos da minha mãe, como uma via que permitiria a suas filhas acessarem uma melhor condição social que ela, permanecendo perto da família e do trabalho no campo, não teve. Mas, essa não é uma interpretação racional e não resiste a nenhuma análise objetivada da minha subjetividade. Então, eu devo evocar meu ingresso no CNRS orientada por Viviane Isambert-Jamati que passou da sociologia do trabalho à da educação? Sem dúvida, mas insuficiente. Se eu liberar minha mente ela me levará a Pierre Naville, um dos fundadores da sociologia do trabalho que, no seu início em início em 1959, declarou xxxiiøé por intermédio da demografia, da economia política e das preocupações da orientação profissional e com uma intervenção estatal cada vez mais ampla na vida pública e privada que as realidades escolares começaram a se inserir no campo da pesquisa social e sistemática". Solicitei, desde o meu ingresso no CNRS, que ele orientasse minha tese, quando era diretor de pesquisa que resultou no livro sobre a Lorraine. Ele me atribuiu, desde nossos primeiros encontros, todas as qualidades de uma pesquisadora potencialmente criativa, me deixando trilhar meu caminho até a defesa onde, em vista dos resultados, ele se declarou decepcionado. É importante lembrar que, nos anos 1970, a especialização em ciências sociais não era frequente como hoje.

Ter tentado reconstituir os primórdios da sociologia do trabalho e sua evolução até os anos 1990 e não a da sociologia da educação encontra, de um lado, sua razão de ser da minha vinculação, naquela data, a um laboratório de sociologia do trabalho, mas também à condição de dois ramos da sociologia. A sociologia do trabalho, sustentada sobre pesquisa de campo forneceram mais referências, manuais, investigações empíricas e de arquivos. De outro lado, a sociologia da educação - mais recentemente, marcada pelas figuras tutelares de Pierre Bourdieu, de Jean-Claude Passeron e seus discípulos -, 
progressivamente endossou as ciências da educação criadas nas universidades pelo Decreto de $1967^{\text {xxxiii. }}$. Essas diferentes razões podem ter me conduzido a essa área, sem me integrar nessa ou naquela especialidade. Ao optar por esse caminho fiquei naquilo que Bourdieu denomina de campos, posição desconfortável para o desenvolvimento de pesquisas, mas indispensável para demonstrar as relações estabelecidas entre elas.

As transformações sociais que operam nos anos 1980-90 sobre o tema das competências, em diferentes esferas de atividades, tais como a economia, o trabalho, a educação e a formação, as quais nos permitiram uma possibilidade nova de observar e analisar suas relações. Fortemente vinculado à ideia de performance e de eficácia em cada uma das áreas, a noção de competências tende, então, a substituir outras que prevaleciam anteriormente, como a de saberes e de conhecimentos na esfera educativa ou a de qualificação no trabalho. Muito embora essas noções não desapareçam, elas perdem a posição central e, associadas às de competências, elas sugerem outras conotações. Em suma, a noção de competência se torna uma noção, testemunho da nossa época. Françoise Ropé e eu buscamos identificar as mudanças, a caracterizar suas orientações, de forma a trazer à tona as homologias que elas apresentam. Para isso, reunimos pesquisadores de diferentes disciplinas indo da sociologia à psicologia cognitiva e passando pela didática, cada um tratando o tema de formas específicas. Assim, procuramos tecer uma analogia existente entre as técnicas, as categorizações aplicadas nas empresas para identificar e avaliar as competências dos trabalhadores em exercício e as utilizadas nas instituições escolares para definir os saberes a serem transmitidos aos estudantes e, em seguida, avaliar os saberes adquiridos. Seguramente, não deixamos de apresentar essas homologias como resultado de processos, de cadeias de relações muito diferentes, mas nos pareceu primordial não perder de vista "o paralelismo das transformações sociais", pois uma das "tarefas" das ciências sociais consiste em evidenciar "a orientação comum a todas as transformações das relações humanas, não somente em uma esfera particular, mas em todas as esferas" (Norbert Elias, 1970, 1986 ${ }^{\text {xxxiv }}$ ). A emergência das noções comuns, como a de competências, testemunha as transformações transversais em uma sociedade e sua interdependência.

A concepção e a recepção de uma obra coletiva que eu dirigi nos anos 1980, L'introuvable relation formation-emploi (1986) já haviam me provado a necessidade imperiosa para pesquisadores e pesquisadoras das ciências sociais, de refletirem sobre as ferramentas com as quais pensam, de examinarem as palavras, as noções que utilizam, posto que estas participam da constituição da realidade social. A posteriori, dei-me conta de que, pelo tipo de análise que eu fazia de um questionamento social, esta obra tinha contribuído a dar forma às representações, às políticas que buscavam estabelecer correspondências entre duas ordens de fenômenos separados, a formação e o emprego, e a fazer aparecer essas relações como necessárias, enquanto seu propósito era o oposto. Em síntese, em muitos aspectos, esse livro confrontava uma propensão a falar da "relação formaçãoemprego" no singular e substantificar os fenômenos que só podem ser pensados em termos de processo. A maioria dos estudos realizados hoje sobre o tema indica a formação como a condição primeira de acesso ao emprego, ocultando as relações sociais que 
presidem a relação entre diploma e lugares na hierarquia social. A exceção das diferenças de sexo consideradas - talvez porque elas se prestem mais facilmente à quantificação, mas, sobretudo porque o movimento de mulheres fez reconhecer essas diferenças como fato social - as desigualdades sociais parecem hoje resultar das desigualdades escolares.

Essa obra foi muito divulgada e, para meu desgosto, fui solicitada a falar em diversos lugares, mas, por uma grande incompreensão sobre seu conteúdo, incompreensão essa que facilitou, pelo seu título, a compreensão dessa relação como necessária e não como detentora de diversas possibilidades.

Questão: Sempre em destaque, no livro Enseigner l'esprit d'entreprise à l'école (2016), você confere uma definição da sociologia e escreve que, enquanto socióloga, "[você] se dedica a caçar os mitos que nos alienam". Podemos ver, nessa definição, implicitamente uma referência à desconstrução das "pré-noções" caras a Émile Durkheim, mas também a reivindicação de uma sociologia emancipadora. Enfim, para você, a que serve a sociologia? Qual foi a recepção dos seus trabalhos? O que você pensa do uso feito pelo poder público dos trabalhos e pesquisas dos sociólogos?

A resposta a uma questão tão vasta quanto o número de sociólogos só pode ser plural. Eu abracei a sociologia como uma ciência que, pelos conhecimentos que ela produz, poderia contribuir para a orientação das transformações sociais por mais justiça, igualdade, solidariedade ou por valores que me animaram na vida. Ao longo do tempo, eu precisei abandonar essa ambição e recorrer a outros objetivos mais acessíveis: compreender o mundo em sua diversidade, produzir conhecimentos originários de pesquisas de campo que fossem verificáveis. Eu reafirmo a mim mesma, as ciências sociais devem mostrar que não há evolução necessária e que toda situação problemática contém várias respostas possíveis, com probabilidades desiguais de atualização. Uma missão a mim confiada pelo secretário de Estado do ensino técnico e profissional (em 1990) foi, para mim, a ocasião de implementar uma abordagem que invalidava a ideia de que uma política de avaliação do nível de formação era necessária. Esse órgão de Estado solicitou auxílio para solucionar o desinteresse pelo ensino profissional, ao mesmo tempo em que legitimava as grandes orientações da política escolar do Ministério da Educação Nacional. Tudo me levava a subscrever as razões alegadas para compreender essa situação: a evolução do trabalho, o declínio do trabalho operário, a perda do poder de identificação do operário qualificado em favor da extensão do trabalho técnico, notadamente, com o advento da figura do técnico de ofício. Ao reconstituir a cadeia de relações, que compreende desde a demanda singular de certas categorias de empresas em competências profissionais até a elaboração de uma demanda social geral, anteposta à sua tradução em termos de saberes e saber-fazer a ser transmitido e, enfim, à definição de diplomas correspondentes, o estudo deveria ser possível de mostrar que um crescimento coletivo aparentemente compartilhado (em elevar o nível de formação) ocultava os desacordos profundos e outras evoluções possíveis que estavam contidas naquela situação. Essas divergências indicavam, também, os efeitos perversos de uma política que, ao elevar o nível do baccalauréat, acentuava a classificação das escolas e marginalizava os jovens que não o 
alcançavam e gerando as contradições hoje vivenciadas pelos egressos do ensino médio, identificados com a figura do técnico durante seus estudos e que se encontravam majoritariamente no lugar dos operários. Ao ampliar a investigação e considerando as divergências e as contradições entre o discurso e os fatos, foi possível mostrar que os recursos exacerbados destinados à escola para resolver problemas do trabalho e mais amplamente do emprego, não revelava uma necessidade, mas um conjunto de decisões, de escolhas operadas por essas ou aquelas categorias de atores inscritos em uma conjuntura histórica determinada. Foi possível, igualmente, reconstituir a cadeia de ações coletivas e individuais (ou ao menos seus principais elos) para mostrar como esses haviam privilegiado essa orientação em detrimento de outras possíveis.

Essa missão foi, portanto, a ocasião de retornar ao papel do sociólogo que compreende, eu diria, sobretudo em uma situação de conhecimento público. Como destaca Norbert Elias, "é objetivando sua própria posição que o pesquisador pode instituir uma distância em relação às dependências que o limitam sem que ele saiba..(e que logra) a separar o saber 'científico' das representações imediatas, de preconceitos espontâneos" , numa situação de peritagem pública. ${ }^{\mathrm{xxv}}$ Se todo mundo concorda em dizer que essa tarefa consiste em dar conta do real, não há necessariamente um acordo em dizer que o real não se confunde com as formas objetivamente atualizadas. Isso porque o real compreende igualmente o não-atual, as possibilidades que foram descartadas. Se bem que a compreensão dos fatos atualizados supõe confrontá-las às possibilidades contidas nas situações observadas. Assim, uma sociologia crítica, que eu reivindico, é uma sociologia de possibilidades e não uma sociologia da necessidade.

Esse relatório teve apenas uma influência limitada sobre a política escolar, pois a resposta aportada ao problema indicado na missão foi reduzida a restaurar um diploma (o CAP) que certificava uma qualificação operária e que a escola invalidava. Nossas análises dificilmente teriam sido divulgadas se não tivessem atendido a certas expectativas e interesses. Ao evidenciar as contradições geradas por uma política "de elevação de nível", de substituição de competências técnicas pelas profissionais, em um sistema produtivo considerado equivocadamente homogêneo, esse relatório foi muito debatido e utilizado para debate. Ele foi, pelas mesmas razões, descartado por uns e usado por outros, seja essencialmente pelos meios profissionais (sindicatos de professores dos liceus profissionais, sindicatos de trabalhadores, organismos de formação contínua de professores, organizações e associações profissionais patronais, organismos de inserção profissional de jovens etc.). Em síntese, a recepção feita por esse relatório expressava a solidez do ponto de vista que eu havia adotado no início: reformular a demanda que me foi feita, compreender os problemas sociais que ele ocultava, esclarecer as escolhas possíveis contidas no momento, especificando seus sentidos e seus efeitos, para, então, instruir os atores envolvidos, em lugar de auxiliar a tomada de decisão e de guiar as políticas.

Esse exercício me fez tomar consciência da profundidade do fosso que separa o mundo do trabalho do mundo escolar, já lamentado pelos reformadores do pós-guerra. Para os 
representantes dos trabalhadores, esse relatório foi um reconhecimento do seu trabalho e da sua dignidade. Mas, contrariamente, a maioria dos funcionários da alta administração da Educação Nacional (reitores das academias, inspetores) e os professores do secundário rejeitaram violentamente a análise e as conclusões feitas. Para eles, eu "falava como os patrões", eu me opunha "a que os operários se tornassem formandos do ensino médio" e, ainda, "eu queria livrar as universidades desses egressos imundos". O Secretário de Estado, ele mesmo, anulou de um dia para outro a entrevista coletiva à imprensa, fazendome saber que esse relatório era irrelevante, pois não respondeu à questão que me foi colocada.

Em seguida, retomei a maneira como eu havia cumprido essa missão oficial, a fim de colocar em perspectiva a atividade de especialista com aquela da pesquisa acadêmica e, de forma geral, de reconhecer as diferentes formas de produção dos conhecimentos sobre o mundo social. ${ }^{\text {xxxvi }}$

Dito de outra forma, um pesquisador pode, inconscientemente, acompanhar uma política sem ter decifrado seu sentido (fazer da formação um instrumento capaz de assegurar o equilíbrio do emprego) ou, inversamente, mostrar que as transformações impulsionadas acentuam as desigualdades sociais. Durante a missão fui aconselhada a evitar o termo "operário", depreciado pelos estudantes e pelos próprios professores. Em resposta, eu intitulei o relatório publicado pela Documentation française ${ }^{25}$ Quelle formation pour les ouvriers et les employés en France ? xxxvii

Questão: Em um número de 1989 da [Revista] Formation Emploi na qual você contribuiu, Pierre Caspard lançou no posfácio um grito de alarme, desde então célebre, face ao "canteiro deserto" xxxviii $\gg$ do ensino técnico e profissional. Onze anos mais tarde, você publicou um estado da arte na Revue française de pédagogie, e afirmou que "os estudos sobre os estudantes [do ensino profissional], sua morfologia social, seus comportamentos e suas representações, que eram privilegiadas nos anos 1960-1970, parecem desprezadas hoje. Como se explica esse desinteresse pelo ensino técnico e profissional, que você destacou "custos em conhecimento" em um artigo publicado em 2005 na Revista Éducation et Sociétés ? Você vê hoje alterações em relação ao balanço feito em 2000, sabendo que Pierre Caspard em 2003, em um colóquio em Villeneuve d'Ascq sobre essa questão, mencionou que doravante a história da formação profissional tornava-se uma "encruzilhada" em lugar do canteiro deserto?

É importante recuperar o deslize semântico para saber sobre o que falamos. O "canteiro deserto", segundo expressão citada de Pierre Caspard, era concernente essencialmente ao ensino profissional, suas instituições, seu público, seus professores, seus modos de socialização. Hoje, a noção de formação profissional tornou-se central e vai além do âmbito escolar, correlativamente à ampliação da aprendizagem não mais vinculada aos saberes do métier e também à formação em alternância que se estende a toda a gama de

\footnotetext{
${ }^{25}$ Editora pública voltada à difusão de informações públicas desvinculadas dos interesses privados (N.T.).
} 
diplomas para além do baccalauréat. Em lugar de tentar mensurar a extensão dos modos de obtenção dos diplomas, talvez deveríamos examinar as mudanças engendradas a partir da inscrição dos problemas do emprego e da economia no centro das política educacionais, a redefinição das missões do aparelho escolar no que tange ao desenvolvimento de uma "formação ao longo da vida" e, em geral, uma perda de autonomia conquistada pela escola ao longo de sua história.

A ideia de formação, sinônimo de bem universal, findou por ser dividida após um longo trabalho de persuasão. Assim, embora construída para fins técnicos, intensamente discutidas pelos representantes do mundo profissional, as nomenclaturas de formação são agora utilizadas pelos organismos, tais como $\mathrm{CEREQ}^{26}, \mathrm{INSEE}^{27}$ e os serviços de estudos estatísticos e de prospecção do Ministério da Educação Nacional. Elas se assentaram nas representações duráveis do mundo social e foram progressivamente impostas como categorias de percepção comuns que orientam as políticas públicas, mas também os comportamentos individuais. A perenidade dessas nomenclaturas traduz a força das representações e das convicções coletivas que as sustentam e resultam da convergência de ações conduzidas, durante os anos 1960-70 em diferentes espaços na sociedade e cujo Plano a fez como síntese. São muitos os fatos que estão na origem da expressão "a relação formação-emprego", hoje assimilada a um nome comum que designa algo estabelecido.

Não podemos deixar de destacar o quanto os diferentes espaços nos quais a formação contínua se concretizava, foram simultaneamente espaços de reflexão e de experimentação pedagógica e originaram princípios que, em seguida, foram codificados e estendidos à formação inicial - e visto, de uma maneira progressista -, a todos os segmentos do sistema escolar e mesmo na universidade.

O modelo pedagógico das competências representa talvez o exemplo mais eloquente da transformação pedagógica que invadiu a instituição escolar após a publicação, em 1991, do "Programa curricular", um conjunto de princípios diretivos segundo os quais os conteúdos de ensino da escola primária ao ensino médio deveriam ser redefinidos; nesse texto, a noção de competências é constantemente mencionada.

A educação e a formação foram, uma e outra, construídas como instrumentos e pilares de uma mudança de envergadura, mas seguida de orientações diferentes. A educação foi pensada como um vetor de um futuro a ser concretizado por meio do registro político, enquanto a formação é, desde o início, mais fortemente atada ao regime econômico. A educação, assim como o lugar no qual se realiza, a escola, são constituídos na França, ao fim dos conflitos que lhes imprimiram marcas de neutralidade e laicidade, as quais são sempre objeto de mobilizações sociais em defesa dos pontos de vista contrários. A formação é uma atividade onde a cooperação entre atores se dá sem grandes disputas para lograr um acordo. Esse acordo constrói-se, no interior da ambivalência, mas também no encadeamento de uma acepção do interesse geral associado à definição de uma economia

${ }^{26}$ CEREQ - Órgão público dedicado aos estudos e pesquisas sobre qualificação profissional. (N.T.).

${ }^{27}$ Instituto Nacional de Estatísticas e Estudos Econômicos (N.T.). 
competitiva, de uma "modernização" da sociedade, do estabelecimento das instituições participantes e de um diálogo social, inscrito em um contexto de busca da redução de conflitos sociais e políticos.

A perspectivação das transformações sociais nas quais as políticas educacionais e de formação foram feitas tateadas pelos coletivos de pesquisadores franceses e europeus. Os títulos das minhas publicações ilustram essa incerta na análise histórica e comparativa: Éducation et travail, en Grande-Bretagne, Allemagne et Italie ${ }^{x x x i x}$, "La formation permanente, entre travail et citoyenneté" (numéro spécial d'Education permanente, 2001, $\mathrm{n}^{\circ} 149$ )

Eu deixarei aos colegas mais jovens o cuidado de discutir essa interpretação e de trazer respostas mais precisas a essa questão de mudar de um campo desértico à encruzilhada multidirecional.

Questão: Como sua experiência de mulher sociológica inscrita em um universo sociológico dominado (e imposto) nutriu sua reflexão a esse respeito? como você se integrou (ou não) e conforme seus trabalhos e publicações, a questão das relações sociais de sexo e de gênero? Você poderia identificar os mecanismos, as questões ou encontros ou redes de pesquisadores e pesquisadoras que parecem ser os mais estimulantes sobre esse tema? Como essa perspectiva fez, ou não, sentido em suas pesquisas sobre o ensino profissional?

Devo admitir que eu, muito tardiamente, tomei consciência sobre as relações de dominação de gênero no exercício da pesquisa. As relações de classe me eram mais evidentes, elas estavam em primeiro lugar para mim. Eu atribuía todos os obstáculos que encontrei às condições sociais. Quando eu ingressei no CNRS, eu tive como parecerista Raymond Boudon que me apoiou sem jamais fazer qualquer referência à minha condição de mulher, nem à minha orientação intelectual. Ele, simplesmente, me disse: "você trabalha com Viviane Isambert que é uma durkheiminiana. Venha me ver se você quiser ouvir outro sino". Pierre Naville, meu orientador de tese, me acolheu como uma discípula possível porque ele dizia que eu era um caso sobre 1000 em razão das minhas origens! Aparentemente nada me remetia à condição de mulher. A posteriori, eu penso que a disciplina de trabalho que eu me impus, me fez reconhecer que esse era o meu lugar. Contudo, eu vivi algumas raras agressões verbais de colegas homens, quando eu me encontrei em posição de poder (bem irrisório) como tomar a iniciativa de realizar pesquisas coletivas e, deste fato, responsável pelo seu desenvolvimento ou ainda após as defesas de tese quando meu julgamento não agradava ao orientador.

Eu provei outra experiência discriminatória quando da realização da missão oficial que o Secretário do ensino técnico e profissional me confiou em 1990, um pouco após a proclamação da palavra de ordem proferida por Jean-Pierre Chevènement, então Ministro da Educação Nacional " $80 \%$ de uma faixa etária com ensino médio completo" (mencionado acima). A interpretação desta frase eminentemente ambivalente foi feita a 
partir de um trabalho pesado de investigação quantitativa (assistida por colegas do CEREQ e DEP) e de enquetes realizadas junto aos: dirigentes de empresas, representantes de associações profissionais patronais, ocupantes de cargos da alta administração da Educação nacional e das regiões, todos homens investidos de uma autoridade que eles exerciam com força nos meios masculinos. Eu, mulher, socióloga, de baixa estatura, eu estava, a priori, desprovida de toda legitimidade e era olhada dos pés à cabeça com ar interrogador.

Também em situações que, paradoxalmente, me provocaram um sentimento de ser um tipo de porta-voz daqueles que eu sentia serem vítimas daquela política.

Fortemente independente, em busca de igualdade, sensível à humilhação, eu me coloquei em pé de igualdade com os que eu percebia como adversários. Aos representantes das pequenas e médias empresas, que me felicitavam por ter mostrado o valor de uma formação profissional sancionada pelo CAP, eu respondia que eles contribuíram para sua desvalorização pelas condições sociais de trabalho manual e com baixos salários concedidos aos operários e aos empregados. Aos representantes da UIMM (União das indústrias metalúrgicas e de minério) que afirmaram que as empresas do setor só selecionariam pessoas com $\mathrm{BTS}^{28}$, eu recordei as objeções dos que haviam devolvido suas cartas de adesão, assim que a oposição das empresas das regiões da Alsácia e Lorena confrontaram as empresas alemães que recrutavam estudantes e aprendizes portadores de certificado CAP no mercado de trabalho nas zonas fronteiriças. Além disso, suprimiram várias formações em métiers de mecânica que hoje são muito demandados em diversos segmentos da indústria como a de reparação naval, aeronáutica, automobilística, nuclear. Entre eles, também o de calderaria e da soldagem, então considerada ultrapassada e são agora deficitários. ${ }^{\mathrm{xl}}$

Assim, eu pude derrubar as barreiras de gênero nesse tipo de situação.

No mundo científico, eu percebi, com outros, que em situações de tomada de decisões comitês científicos, banca de seleção, comitês de redação de revistas - a palavra de uma mulher não tinha o mesmo peso que a de um homem.

Nas situações de pesquisa, eu compreendi que a primeira condição a ser preenchida para remover os preconceitos é, sem dúvida, respeitar o outro. Eu experimentei isso (assim como Catherien Agulhon e A. Poloni) na pesquisa sobre os professores do ensino profissional, todos, sem exceção, eram do sexo masculino. Diante de uma desconfiança espontânea em relação às "damas do CNRS", nos colocaram à prova de múltiplas maneiras de modo que as primeiras entrevistas, nós tivemos que mostrar nosso interesse por questões técnicas e mostrar que tínhamos um conhecimento mínimo para obter informações, destacadamente sobre as práticas de transmissão de saberes técnicos e

\footnotetext{
${ }^{28}$ Brevê técnico superior, diploma existente desde 1962 na França e pode ter formação de dois anos após conclusão do ensino médio - equivalente aos cursos sequenciais - ou de quatro anos, correspondente à formação tecnológica no Brasil. (N.T.)
} 
profissionais. Para isso tivemos, cada uma a sua maneira, que adquirir certa familiaridade com as máquinas, com as definições das principais noções técnicas, enfim, aprender a empregar uma linguagem técnica, ainda que aproximativa. ${ }^{\text {xli }}$

Paradoxalmente, nosso estatuto e nosso sexo, se nos tornavam handicaps para registrar certas questões, tornaram-se vantagens na coleta de informações sobre temas tidos como de caráter privado, a exemplo das relações pais e filhos ou sobre aspectos psicológicos, questões essas extremamente vivas na memória dos professores que nos confessaram terem sofrido na pele a passagem de operário à função de professor.

Para concluir, eu diria que eu não tive o sentimento de ter sido prejudicada na minha carreira como pesquisadora, no máximo eu vivenciei situações marcadas pelo preconceito, das quais eu me defendi e duas ou três humilhações que despertaram outras muito antigas, das quais eu não pude me livrar, por falta de dispor de meios necessários. Eu devo, portanto, reconhecer que eu apaguei as relações de dominação de gênero no ensino profissional, na pesquisa, e mesmo, de certa maneira, no trabalho em geral, ao dar toda importância às relações de dominação de classe.

Vocês, que me solicitaram essa entrevista, e os pesquisadores (as) aos quais estão vinculados, assim como os(as) antigos(as) doutorandos(as), consertem essa parte sombria e será um grande avanço na sociologia.

Questão: Ao longo do seu trabalho de pesquisa, da qual uma parte feita a partir dos arquivos, você articulou imagens (fotos, filmes etc.) relativas ao ensino técnico ou profissional ou ao trabalho. Qual foi sua atitude face a esse material que os sociólogos normalmente evitam ou desprezam? Você parou aí? Você guardou algum? Se sim, qual eventual projeto? Alguns te marcaram mais particularmente? Você poderia nos mostrar alguns e comentá-los?

As imagens eram raras nos arquivos que eu pesquisei, exceto aquelas das salas de aula que revelam rostos e corpos mais velhos que os de hoje. Nos anos 1970-80 a imagem ocupava pouco espaço nas análises e ainda menos nas publicações. Bourdieu insistia muito sobre a descrição dos lugares de vida, dos corpos, da vestimenta, da linguagem que nutria as entrevistas, mas nós não tínhamos aparelhos fotográficos. A imagem não tinha o espaço que tem hoje onde ela invadiu todos os momentos da vida

Por outro lado, eu conservei na memória imagens mentais de professores em suas oficinas, frente aos estudantes e frente a mim mesma. Vem-me à mente a imagem de onde eles me aguardavam atrás das grandes vidraças da oficina e me recebiam em seguida com ironia. "Mas, você sabe dirigir! [automóvel]!". Igualmente, me lembro de um homem, ex-operário qualificado que se tornou professor porque sua carreira foi bloqueada na fábrica e ele sofreu na pele e na sua dignidade a conversão para se tornar professor: ele se exercitava falando no espelho para tentar evitar os "tiques" da linguagem que os estudantes não se cansavam de imitá-lo. As imagens "materializadas" que permanecem 
na cabeça são aquelas dos filmes destinados a serem projetados, onde o trabalho é idealizado, a exemplo do operário da siderurgia face aos perigos do métier que o homem vai controlar. São imagens, ao mesmo tempo, edificantes quanto alienantes.

Imagem 8: Capa do livro "A sociologia do trabalho na França: enquete sobre o trabalho dos sociólogos, 1950-1990, Paris, La Découverte, 2011.

A imagem se introduz hoje nos livros universitários porque elas têm virtudes próprias. Os editores a utilizam frequentemente esse recurso, notadamente para ilustrar as capas. É assim que no meu livro sobre "a sociologia do trabalho" o texto é reforçado pela imagem das operárias na telefonia. ${ }^{x \text { lii }}$ Proposta, entre outras, pelo editor, eu aceitei sem reservas, pois mostrava mulheres no trabalho, um tipo de trabalho pelo qual eu não me interessava.

A escolha da imagem impressa na capa do outro livro intitulado "Enseigner l'esprit d'entreprise à l'école", que representa uma mão cheia de moedas, respondia a duas exigências de naturezas distintas: poder ser reproduzida gratuitamente e evocar o sentido que eu queria dar à análise desenvolvida no corpo do texto. xliii Já fui muito criticada por reduzir a empresa à lucratividade, crítica justa e inegável. Mas, à medida que foi importante para mim mostrar que as empresas estavam sendo convocadas a contribuir para a educação da juventude, por meio das associações de representantes, e com a intenção de inculcar, não somente a aprendizagem dos conhecimentos, mas também valores e comportamentos culturais próprios aos que Max Weber chamou de "espírito do capitalismo"xliv . O capitalismo não designa, para esse autor, um sistema econômico e social fundado sobre a apropriação dos meios de produção como em Marx. Ele se define como uma racionalização instrumental das atividades sociais que exige a formação de esquemas de pensamento antes de invadir todas as esferas da vida coletiva e individual.

Questão: Ao olhar para o seu trabalho de socióloga, mesmo que você continue pesquisando e publicando, você tem arrependimentos? Há coisas que você faria ou teria feito de outra forma? Há renúncias de que você se arrepende?

"Balanço" é uma palavra do comércio definida pela relação entre os ativos e os passivos. Impossível de fazer tais operações sobre os fenômenos sociais que não se deixam reduzir a valores numéricos.

De toda forma, avaliar os eventuais avanços da pesquisa nas ciências sociais nas quais participamos ou que impulsionamos, não pode ser feita se não em escala coletiva, após ter reunido as condições necessárias a esse exercício. Exercício perigoso em um campo onde a diversidade dos pontos de vista se mescla, onde os objetos se resvalam, conforme os problemas sociais do momento. Resta-nos, parece-me, uma postura de espírito que eu denominarei engajamento que nada mais é que não é, de forma alguma, uma denúncia. $\mathrm{O}$ engajamento é, em verdade, uma noção ambivalente que implica uma crítica de uma ordem estabelecida em nome de um futuro definível a partir de objetivos históricos que são acompanhados de um processo de emancipação. Eu conservei esse engajamento ao 
me referir aos objetivos fixados por pensadores progressistas, como os que citei anteriormente, que, em seguida ao fim da Segunda Guerra Mundial, propuseram transformar os conteúdos de ensino, com vistas a superar esta visão alienante que consistia em definir o universalismo essencialmente pelo "ensino geral". Ao contrário, eles avançaram na ideia de um ensino unindo a aprendizagem de um métier à emancipação cultural. Mas o prolongamento da escolarização dos últimos cinquenta anos, efetuou-se preservando a preeminência do ensino geral e depreciando continuamente o ensino profissional, a despeito dos discursos inflamados clamando à valorização, para depois, recentemente, o substituir pelo aprendizado na empresa. Pouco estudado, esse ensino é, portanto, hoje como ontem, o objeto de transformações as mais radicais e as mais políticas. A história mostra que as alterações que os(as) afetam frequentemente anunciam o que mais tarde ocorrerá em outros segmentos do sistema educacional. Um ensino que associa formação ao métier, a uma emancipação cultural permanece, contudo, no horizonte de expectativas a todos que exaltam a justiça social.

Um dos arrependimentos que sempre voltam é a eliminação das controvérsias abertas, argumentadas para evitar uma colisão que esteriliza o avanço dos conhecimentos e das transformações possíveis. Minhas análises sobre o ensino profissional, apoiadas sobre o que continha potencialmente contrariedades aos que viam nesse ensino um aprendizado à disciplina, à obediência às regras da ordem existente nunca deram lugar a qualquer confrontação que fosse. Segundo a tese desenvolvida L'ordre des choses, o CET desempenhou tanto um papel de reparação moral quanto de formação técnica: compensar as lacunas de uma primeira educação "liberada", ensinar aos adolescentes os usos básicos em termos de: espaço (um lugar para cada coisa), tempo (um tempo para cada coisa), conformidade instrumental (utilizar as ferramentas de forma responsável), verbal (chamar as coisas pelo nome), moral e higiênica (se lavar, fazer esporte), ser franco, leal, corajoso, voluntário etc. E os estudantes se opuseram e adotaram reações características da contra aculturação: fugas, brincadeiras de mau gosto, linguagem vulgar, jogos violentos etc. Um retorno a essa tese hoje suscitaria, sem dúvida, severas críticas, pois ela aborda exclusivamente o registro da cultura, da relação entre cultura técnica e profissional e cultura "cultural", "geral", "dominante", negando os saberes a ela vinculados.

Esse tipo de análise ancorada sobre a teoria do livro La reproduction ${ }^{x l v}$, repousa sobre uma concepção do conhecimento e das relações entre conhecimento e ação bastante discutível. Ela postula que existe uma ordem unidimensional de saberes, segundo os quais os saberes técnicos seriam uma aplicação de saberes científicos e os saberes profissionais uma aplicação dos saberes técnicos. Dito de outra forma, ela se apoia sobre uma concepção que nega a exigência de registros específicos de saberes e que impedem a incorporação do ensino tecnológico na cultura escolar. Tal concepção se opõe ao reconhecimento de diferentes formas de excelências e nega a racionalidade da ação no trabalho. Tais são os princípios que me guiaram nas minhas pesquisas. Quase vinte anos separam esses dois pontos de vista, construídos em contextos diferentes e que, vemos, se opõem, mas não se confrontam. 
Uma reflexão crítica seria necessária para remover a opacidade semântica contida no caráter polimórfico desta expressão "uma cultura comum" promovida por uma corrente do pensamento para recuperar a escola igualitária.

Outra decepção, meu fraco conhecimento de outros idiomas (os da minha geração), que me impediram de realizar comparações internacionais, métodos de pesquisa que se impõem hoje na era da globalização. Esses demandavam investimentos intelectuais e financeiros que não possuíamos. As raras tentativas realizadas Éducation et travail, en Grande-Bretagne, Allemagne et Italie 1995 (traduzida para o inglês) realizadas mais frequentemente em colaboração com outras colegas (Anette Jobert, Catherine Marry) ou ainda L'école et l'entreprise, l'expérience des deux Allemagnes (com Annick Kieffer) permaneceram no estado de delimitação das temáticas privilegiadas aqui ou lá, permitindo um interconhecimento de um meio de pesquisa, mas não um conhecimento concreto dos fenômenos em si mesmos.

Eu acrescentaria novamente esse embaraço causado pelas descontinuidades que se opõem à acumulação dos conhecimentos que poderiam estabelecer sobre uma classe de objetos empíricos identificados sobre os modos de pesquisa, as concepções da prova, os critérios de objetividade etc. Mas, com o tempo, eu me libertei dessa vontade obsessiva de "fazer ciência" no senso normativo do termo.

Ao final, eu diria que eu me defino como um "passador" (colocar a palavra no feminino seria desnaturalizá-la) que tenta transmitir as lições de sua experiência de um métier que deve conjugar as exigências contrárias: aquelas referentes à autonomia do pensamento e as ligadas ao engajamento na sociedade do nosso tempo. Examinar as pesquisas realizadas e seus resultados precede a toda perspectiva sociológica. Será válido transmitir as lições de sua experiência, se for feita uma análise reflexiva e não sobre um testemunho. Caso contrário, eu o mostrei, um pesquisador pode acompanhar, involuntariamente, uma política cujo sentido ele ou ela não decifrara ou, inversamente, mostrar que ela acentua as desigualdades sociais. Eu creio ter mostrado a fecundidade de uma sociologia relacional a propósito da emergência após o uso inflado da noção de competências e das modificações que ela designava nas esferas educacional e do trabalho. A tradução dessa obra no Brasil foi feita sobre a constatação de uma difusão desta noção naquele país, que testemunhou igualmente as mudanças transversais àquela sociedade.

Em termos de percurso, eu diria que meu engajamento no munda social guiou a escolha e a divisão dos meus objetos de pesquisa, ao modo de constituição e de tratamento dos dados e às formas de demonstração. Essa postura intelectual associada a uma abordagem sócio-histórica e à combinação de diferentes níveis de análise subjacentes à investigação feita no meu último livro. Ele destaca as principais transformações em curso, ainda em processo, posto ser necessário aprofundar seu significado: um processo de desintegração do serviço público, um deslocamento da minha missão primeira da escola, formar um(a) cidadão(dã) sabendo exercer um julgamento crítico a um sujeito essencial adaptado aos imperativos econômicos, uma substituição de valores coletivos, principalmente os 
relativos à igualdade das projeções de conquistas individuais ${ }^{x l v i}$. Ao longo desses anos, eu tentei conservar um duplo engajamento na produção dos conhecimentos e na ação.

Ainda que relutante, no início, a fazer este exercício, hoje agradecida a Stéphane Lembré e Gilles Moreau, que me convenceram a fazê-lo e me acompanharam ao longo desse retorno à minha experiência profissional como socióloga. Eu lhes agradeço fortemente. Agradeço igualmente a Jean-Paul Géhin pela última leitura e pela formatação do texto para publicação*.

Lucie Tanguy

Pesquisadora associada ao CRESPPA-GTM, CNRS; Diretora de Pesquisa do CNRS Centre National de Recherches Scientifiques, França; professora emérita de Sociologia da Educação na Universidade de Paris V e de Sociologia do Trabalho na Universidade de Paris VII ltanguy2@gmail.com

Sobre Stéphane Lembré Palestrante em história contemporânea na Universidade de Lille e membro do laboratório CREHS (Universidade d'Artois).

Sobre Gilles Moreau

Professor de sociologia na Universidade de Poitiers e membro do GRESCO (Grupo de pesquisa sociológica sobre as sociedades contemporâneas).

\section{Notas}

* Esta entrevista apareceu originalmente na revista francesa Images du Travail, publicada on-line em setembro de 2020, tendo sido autorizada sua publicação nesta edição da revista Cadernos CERU pela editora da revista francesa.

${ }^{i}$ Cf. Pierre Bourdieu (Org.). Un art moyen. Essai sur les usages sociaux de la photographie, Paris: Éditions Minuit, 1965.

ii EPRASS foi criado pela VI seção da EPHE (École Pratique des Hautes Études) e de pesquisadores do CNRS no início do ano letivo universitário de 1965. Esse ensino compreendia quatro disciplinas: sociologia, a mais numerosa (trinta pessoas no máximo), etnologia, psicologia e linguística.

iii À época, o ingresso no CNRS era feito por concurso e apresentação de um projeto de pesquisa, mas a relação entre a quantidade de vagas e o número de candidatos não era nada comparado aos de hoje e, também, as exigências em termos de certificação acadêmica e de publicações em revistas científicas. Sem me alongar sobre isso, é preciso lembrar que nas modalidades de seleção e de funcionamento da pesquisa no CNRS, eram apenas setenta e cinco pesquisadores em sociologia. LAUTMAN, Jacques "Chronique de la sociologie française après 1945", Science théorique de l'opinion publique, hommage à J. Stoetzel, Paris, Retz, 1981.

iv Lucie Tanguy, "L'État et l'école. L'école privée en France", Revue française de sociologie, 1972, 133, p. 325-375. Sobre a Lei Debré de 1959, ver também Bruno Poucet (dir.), L'État et l'enseignement privé : l'application de la loi Debré (1959), Rennes, PUR, 2011.

v Lucie Tanguy, Enseigner l'esprit d'entreprise à l'école. Le tournant politique des années 1980-2000 en France, Paris, La Dispute, 2016.

${ }^{\mathrm{vi}}$ Lucie Tanguy, Le capital, les travailleurs et l'école : l'exemple de la Lorraine sidérurgique, Paris, François Maspero, 1976.

vii Monique Segré-Brun, Lucie Tanguy, "Quelle unité d'analyse retenir pour étudier les variations géographiques de la scolarisation?", Revue française de sociologie, numéro thématique "Sociologie de l'éducation", 1967, 8, 1, p.117-139. 
viii Analisando a evolução da escolarização entre 1964 e 1974, tomando como base 100, em 1969 constatamos que: o ramo profissional oferecido no Colégio de Ensino Técnico (CET) conhece sua evolução mais fraca, passando do índice de 100 para 103; a denominada via de rebaixamento (designando a préaprendizagem e a aprendizagem), passa de 100 para 157, quantos aos liceus, reservados como eram, obtiveram o índice de 100 a 116. Eu destaco que essa evolução não era resultado de um movimento espontâneo, ne resultante de uma soma de comportamentos individuais designados sob o rótulo "desprezo ao ensino técnico", mas o efeito de uma política de Estado, então definida no quadro da carte scolaire [sistema de atribuição das vagas, segundo residência dos estudantes (N.T.)]. Esse processo se desenvolveu sob a tônica das modificações da divisão social do trabalho, incluindo uma massiva desqualificação do trabalho operário: de 1954 a 1968, o número de operários especializados passou de 1.815 .625 para 2.650.380, enquanto o relativo aos operários qualificados passou de 2.837.442 para 2.506.180. Lucie Tanguy, La carte scolaire, instrument d'une politique d'État, Université Paris V, UER Sciences de l'Éducation, 28 rue Serpente 75006.

ix Ver Le capital, les travailleurs et l'école, ch.11, Les CET, un enjeu politique. Patrice Pelpel, Vincent Troger, Histoire de l'enseignement technique, Paris, Hachette, 1993, des filières sélectives, p. 97.

x A técnica em luta, CET, liceus técnicos, já são uma fábrica! Supplément à Libérons l'école, no 1: "40 horas por semana é muito. É muito e não nos permite ter tempo de viver e de pensar um pouco. Por que 40 horas por semana? Quando vemos os companheiros que trabalham, mas não usam 1/10 das bobagens que aprenderam, mas que fazem um trabalho embrutecedor e sempre igual; quando vemos que menos da metade dos estudantes formados nos CETs e trabalham nas áreas em que estudaram, a gente se pergunta: 40 horas por semana não é para nos qualificar profissionalmente, mas sim para NOS HABITUARMOS AOS HORÁRIOS EXAUSTIVOS DA FÁBRICA, que engorda os patrões, mas nos impede de viver e de pensar por nós mesmos e nos levar à lavagem cerebral dos professores e da televisão".

x Jean-G. Padioleau, "Raymond Boudon, L'analyse mathématique des faits sociaux", Annales, Économies, Sociétés, Civilisations, 1969, 24-4, p. 947-948.

${ }^{x}$ Raymond Boudon, Paul Lazarsfeld, Le vocabulaire des sciences sociales : concepts et indices, Paris, La Haye, Mouton\&Co, 1965, Raymond Boudon, Paul Lazarsfeld, L'analyse empirique de la causalité : choix de textes, Paris, La Haye, Mouton \&Co, 1966.

x Jean-Daniel Reynaud, "Sociologie et "raison dialectique"“, Revue française de sociologie, 1961, 2-1, p. $50-66$.

x Ver Emmanuel Droit, Vers un homme nouveau? L'éducation socialiste en RDA : 1949-1989, Rennes, PUR, 2009

${ }^{x}$ Notes et études documentaires $n^{\circ}$ 4669-4670, La Documentation française.

${ }^{x}$ Mona Granato, Gilles Moreau, Les défis de l'apprentissage en Allemagne, Formation Emploi, $\mathrm{n}^{\circ} 146$, 2019, 2, p. 7-28.

x Basil Bernstein, Class, codes and control, London, Routledge and Kegan Paul, 4 volumes, 1971, 1973, 1975, 1990 ; Basil Bernstein, Langage et classes sociales : codes socio-linguistiques et contrôle social, Paris, éditions de Minuit, 1975 ; M.E.D. Young, Knowledge and Control : New directions for the sociology of Education, London, Collier-Macmilan, 1971 ; Jérome Deauvieau, Jean-Pierre Terrail (textes présentés et choisis par), Les sociologues et la transmission des savoirs, dix ans après, Paris, La Dispute, 2017.

'Lucie Tanguy, "Savoirs et rapports sociaux dans l'enseignement secondaire en France", Revue française de sociologie, 1983, 24-2, p. 227-254 ; Lucie Tanguy, "Les savoirs enseignés aux ouvriers", Sociologie du travail, 1983, 25-3, p.336-354 ; Lucie Tanguy, Catherine Agulhon, Françoise Ropé, 'L'enseignement du français en LEP, miroir d'une perte d'identité", Études de linguistique appliquée, n54, p.19-38.

${ }^{x}$ Os IUFM criados em 1990, eram estabelecimentos de formação de profissionais do ensino público (professores dos primeiros e segundo graus, conselheiros da educação). Eles foram substituídos pelas escolas de ensino superior do professorado e da educação (ESPE), e, em seguida, pelos Institutos Nacionais Superiores do Professorado e da Educação (INSPE).

${ }^{x}$ Recyclés est ici synonyme de formés.

${ }^{x}$ Lucie Tanguy, L'enseignement professionnel en France : des ouvriers aux techniciens, Paris, PUF, 1991

${ }^{x}$ Claude Grignon, L'ordre des choses : les fonctions sociales de l'enseignement technique, Paris, éditions de Minuit, 1971.

${ }^{\mathrm{x}}$ Lucie Tanguy, "La mise en équivalence de la formation avec l'emploi dans les IVe et Ve Plans (19621970)", Revue française de sociologie, 43-4, 2002, p. 685-709.

x Pierre Caspard, "Un chantier déserté : l'histoire de l'enseignement technique", Formation Emploi, nºspécial, L'enseignement technique et professionnel, repères dans l'histoire (1830-1960), 1989, $\mathrm{n}^{\circ} 27-28$, p. 193-197.

${ }^{\mathrm{x}}$ Lucie Tanguy, Histoire et sociologie de l'enseignement technique et professionnel : un siècle en perspective, Revue française de pédagogie, 2000, n¹31, p. 97-127. 


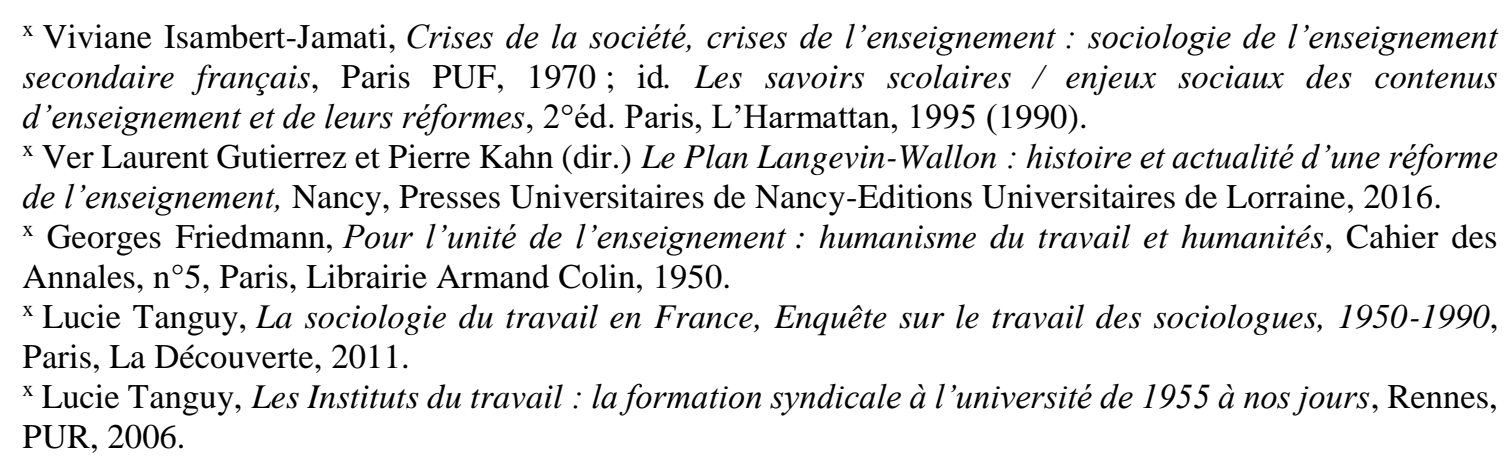

x Fernand Braudel, "Histoire et sociologie", dans Georges Gurvitch (dir), Traité de sociologie, Paris, PUF, 1958, republicado em Fernand Braudel, Ecrits sur l'histoire, Paris, Flammarion, 1969, p. 97-122.

${ }^{x}$ Pierre Naville, École et société, Paris, Librairie Marcel Rivière, 1959 ; Pierre Naville, Théorie de l'orientation scolaire et professionnelle, Paris, Gallimard, 1945, 1972; Pierre Naville, La formation professionnelle et l'École, Paris, 1948. Na época desse exercício, eu encontrei uma publicação esquecida que apresenta os traços deixados por P. Naville sobre as minhas perspectivas de pesquisa na homenagem realizada por Michel Éliard, Pierre Naville, La passion de la connaissance, L. Tanguy, "P. Naville, 19421960, une sociologie des relations", Toulouse, Presses du midi, 1996.

${ }^{x}$ Françoise F. Laot et Rebecca Rogers, Les sciences de l'éducation, émergence d'un champ de recherche dans l'après-guerre, Rennes, PUR, 2015.

${ }^{x}$ Françoise Ropé, Lucie Tanguy (dir.), Savoirs et compétences : de l'usage de ces notions dans l'école et l'entreprise, Paris, L'Harmattan, 1994 (Saberes e competências, Sao Paulo 1996).

x Norbert Elias, Qu'est-ce que la sociologie ? rééd. La Tour-d'Aigues, éditions de l'Aube, 1996 (1970), p. 73-76.

${ }^{x}$ N. Elias, Engagement et distanciation, Paris, Fayard, 1993, chap. 1

${ }^{x}$ Lucie Tanguy, "Le sociologue et l'expert, une analyse de cas", Sociologie du travail, 1995, 37-3, p. 457477.

x Paris, La Documentation française, 1991.

${ }^{x}$ Expressão utilizada por Pierre Caspard, no posfácio do número especial da revista Formation Emploi, dedicada ao "l'enseignement technique et professionnel. Repères dans l'histoire (1830-1960)" : Pierre Caspard, “un chantier déserté : l'histoire de l'enseignement technique", Formation Emploi, n²7-28, 1989, p. 193-197.

${ }^{x}$ Annette Jobert, Catherine Marry, Lucie Tanguy, Education et travail, en Grande-Bretagne, Allemagne et Italie, Paris, Armand Colin, 1995, Annette Jobert, Catherine Marry, Lucie Tanguy and Helen Rainbird (dir.), Education and Work in Great Britain, Germany and Italy, London and New York, 1997 ; Lucie Tanguy, Philippe Casella, Guy Brucy (dir.), "Entre travail et citoyenneté, la formation permanente. France, Allemagne, Suède", Éducation permanente, 2001, $\mathrm{n}^{\circ} 149$.

${ }^{x}$ Ver l'Usine nouvelle, 2-12-2016 et 30-3-2016. Entre os exemplos citados, o da EDF (Électricité de France), produtor e distribuidor de eletricidade que diz ter recebido apenas 30 respostas para um anúncio de caldeireiro contra 300 para vagas administrativas.

x Ver Catherine Agulhon, Arlette Poloni, Lucie Tanguy, Des ouvriers de métiers aux diplômés du technique supérieur : le renouvellement d'une catégorie d'enseignants en lycées professionnels, Paris, Ministère de l'Éducation Nationale, CNRS, 1988.

${ }^{x}$ Ouvrières chez Telefunken, 1958.

x Iustração da capa: tesouro de Laniscat (Côtes d'Armor) 2007. Descoberto em uma exploração agrícola na Idade do Ferro, o tesouro de Laniscat é composto por 58 estáteres e de 487 quartos de estáteres. Todas essas moedas foram tomadas pelo poder osismo ao longo da primeira metade do século I a.c., Institut national de recherches archéologiques préventives, RMN-Grand Palais, photo Hervier Paitier.

${ }^{x}$ Max Weber, L'Ethique protestante et l'esprit du capitalisme (1904), Plon, Paris, 1967.

x Pierre Bourdieu, Jean-Claude Passeron, La Reproduction, Paris, éditions de Minuit, 1970.

${ }^{x}$ Lucie Tanguy, Enseigner l'esprit d'entreprise dans l'école, op. cit. 
